\title{
Folliculotropic mycosis fungoides
}

INSERM

\section{Source}

INSERM. (1999). Orphanet: an online rare disease and orphan drug data base.

Folliculotropic mycosis fungoides. ORPHA:178512

Folliculotropic mycosis fungoides is a rare variant of mycosis fungoides (MF; see this term), a form of cutaneous T-cell lymphoma, and is characterized by the presence of folliculotropic infiltrates in patch-plaque lesions usually involving the head and neck area. 